\title{
MULTICRITERIA DECISION ANALYSIS: A MULTIFACETED APPROACH TO MEDICAL EQUIPMENT MANAGEMENT
}

\author{
Ilya IVLEV', Peter KNEPPO ${ }^{\mathrm{a}}$, Miroslav BARTÁK ${ }^{\mathrm{b}}$ \\ ${ }^{a}$ Department of Biomedical Technology, Czech Technical University in Prague, \\ Nam. Sitna 3105, 27201 Kladno, Czech Republic \\ ${ }^{\mathrm{b}}$ Department of Social Work, Jan Evangelista Purkyně University in Üstí nad Labem, Czech Republic
}

Received 23 January 2014; accepted 04 May 2014

\begin{abstract}
Selecting medical equipment is a complex multidisciplinary task requiring mathematical tools, considering associated uncertainties. This paper offers an in-depth study of multiple-criteria decision analysis (MCDA) methods to identify the most appropriate ones for performing management tasks in resource-limited settings. The chosen articles were divided into three topics: evaluation of projects and equipment, selection of projects and equipment, and development of medical devices. Three methods (analytic hierarchy process [AHP], multi-attribute utility theory and elimination and choice expressing reality) were selected for detailed analyses of their application for medical equipment management. Twenty-one work using MCDA, artificial neural networks, human factors engineering, and value analysis were analysed in the framework of medical equipment management. The important aspects of the procedure were described, highlighting their advantages and disadvantages. It was determined that the AHP approach corresponds to all defined criteria for selecting large medical equipment. Managing large medical equipment using MCDA will reduce uncertainties, and provide a rational selection and purchase of the most efficient equipment in resource-limited settings. The direction for improving the AHP method was determined.
\end{abstract}

Keywords: analytic hierarchy process, decision theory, multi-criteria decision making, operations research, procurement, medical technologies.

JEL Classification: C44, C65, D81, H57.

\section{Introduction}

Technological progress and innovation are generally considered to be the main drivers of economic growth in advanced economies. In addition, medical technology is specifically credited for raising the expectancy and quality of life (Willemé, Dumont 2013). At the same time, it is also commonly considered to explain the surge in health expenditures in recent decades (Willemé, Dumont 2013).

Corresponding author Miroslav Barták

E-mail: miroslav.bartak@ujep.cz 
In general, health spending in OECD (Organisation for Economic Co-operation and Development) countries grew on average by close to 5\% year-on-year from 2000 to 2009; this has since been followed by a sluggish growth of around $0.5 \%$ in 2010 and 2011. Current expenditure on health (i.e. excluding capital expenditure) grew by $0.7 \%$ in both years. Preliminary figures for some countries suggest a continuation of this trend in 2012. Health spending accounted for $9.3 \%$ of GDP on average across OECD countries in 2011, compared with 9.5\% in 2010. Excluding capital spending, current expenditure on health as a share of GDP dropped from 9.1\% on average in 2010 to 9.0\% in 2011 (OECD 2013).

According to Willemé and Dumont calculations based on 18 OECD countries data from 1981 to 2009 , medical technological change accounted for as much as $69 \%$ of the explained growth of total real per capita health expenditures over the 1981-2009 period (Willemé, Dumont 2013). Since they did not attempt to correct for medical price inflation, this estimate is probably biased upward. There is ongoing discussion in the literature to this issue. The overview of the estimated impact of the expenditures drivers is presented in the Table 1. There is a commitment that the technologies accounting the highest share but the assumptions varied considerably.

Table 1. Contributions of selected factors to growth in health care spending in \%

\begin{tabular}{l|ccccccc}
\hline & & & & & & & \\
\hline
\end{tabular}

Notes: ${ }^{\star}$ Not estimated; ${ }^{*}$ included aging, but also "front page treatments" (i.e. media coverage drives demand for expensive treatment), increased preventive and diagnostic activity, and consumers moving away from less expensive managed care products; ${ }^{* * *}$ included government mandates (including new mandated benefits) and federal and state regulatory requirements.

Source: Sorenson et al. 2013.

Reports published by the World Health Organization (WHO) indicate that the rising financial costs in the global system of public health are caused by mistakes in the control system and misuse of funds (World Health... 2010b). The paramount reasons for financial losses, as stated by WHO, are the malfunction of the acquisition system, and misuse and poor control of technical resources (World Health... 2010b). 
The need to create a system for the rational management of large medical equipment at medical institutions worldwide has become of prime importance. This is due to several reasons, including the undeveloped management systems for large medical equipment, the rapid growth of large medical equipment markets and financial markets (Skinner 2013; World Health... 2013), and the high volume of medical equipment that is partially or fully unfit for use, accounting for $50 \%$ globally, and as high as $80 \%$ in some countries (Voronin 2003). One of the most crucial questions in creating the management system for medical equipment concerns the identification of the appropriate method.

The purpose of this paper is to identify multiple-criteria decision analysis (MCDA) methods which can be applied to the task of medical equipment selection. The article identifies advantages and weaknesses of some of the MCDA methods and suggests methods for improving the most appropriate methods.

A search of the literature was conducted using the following databases: CINAL, IEEE Explore, MEDLINE, PsycINFO, PubMed, ScienceDirect, SpringerLink, and Wiley Online Library. A combination of the following key words and phrases were inputted into these databases: Analytic Hierarchy Process (AHP), Analytic Network Process (ANP), ELimination and Choice Expressing REality (ELECTRE), Goal programming, Grey relation analysis, Markov process, Technique for Order of Preference by Similarity to Ideal Solution (TOPSIS), VIseKriterijumska Optimizacija (VIKOR), and related words. The Medical Subject Headings controlled vocabulary thesaurus was used.

\section{MCDA: applications in medical equipment management}

Multicriteria decision analysis (MCDA) is widely used in economics (Zavadskas, Turskis 2011). MCDA has been used to support decision making in healthcare management (Table 2) and also in many others fields like road networks planning (Zolfani et al. 2011), portfolio management (Fotr et al. 2013), creative industries analysis (Slach et al. 2013) Steps are being taken to identify the main parameters and to issue recommendations, as well as to create various models to reduce the risks in making managerial decisions in healthcare (World Health... 2010b). On one hand, modern materials describing decision making (World Health... 2010a) do not go beyond defining the need for the new equipment, replacement of the old one, and the abilities of a medical institution. On the other hand, some tools reveal the most critical technical parameters (Lerski et al. 2010) that are sufficient for the equipment to fulfil its clinical tasks.

\subsection{Selection of projects and equipment}

The methodological recommendations for the purchase of medical equipment (Angelo 2009) include a range of organizational and technical questions that the decision maker (DM) needs to answer in the process of choosing the equipment.

The MCDA techniques have been used (Table 1) in both evaluation and selection of projects and equipment. Balestra et al. (2007) applied the analytic hierarchy process (AHP) to support the acquisition of pacemakers and implantable defibrillators. Chatburn and 
Table 2. MCDA applications for medical equipment management

\begin{tabular}{|c|c|c|c|}
\hline $\begin{array}{l}\text { Field of } \\
\text { application }\end{array}$ & Author/s / Year & The method & $\begin{array}{l}\text { The decision-making } \\
\text { framework }\end{array}$ \\
\hline \multirow{14}{*}{ 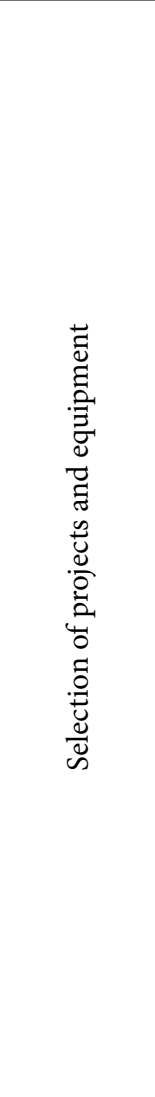 } & Balestra et al. 2007 & \multirow[t]{8}{*}{ AHP } & $\begin{array}{l}\text { evaluation of the quality and } \\
\text { selection of cardiac pacemaker }\end{array}$ \\
\hline & Chatburn, Primiano 2001 & & selection of a medical ventilator \\
\hline & Cho, Kim 2003 & & $\begin{array}{l}\text { selection of consumables and } \\
\text { medical devices }\end{array}$ \\
\hline & Pecchia et al. 2013 & & selection of a CT \\
\hline & Montevechi et al. 2010 & & $\begin{array}{l}\text { selection of an ultrasound imaging } \\
\text { device }\end{array}$ \\
\hline & Sloane 2004 & & selection of a neonatal ventilator \\
\hline & Hummel 2001 & & $\begin{array}{l}\text { evaluation of an artificial cardiac } \\
\text { valve }\end{array}$ \\
\hline & Mundzhed 2008 & & $\begin{array}{l}\text { selection of electrocardiographs } \\
\text { for first-aid stations }\end{array}$ \\
\hline & Arikan, Kucukce 2012 & AHP, PROMETHEE II & $\begin{array}{l}\text { evaluation and selection of } \\
\text { suppliers }\end{array}$ \\
\hline & $\begin{array}{l}\text { Velmurugan, } \\
\text { Selvamuthukumar } 2012\end{array}$ & ANP & $\begin{array}{l}\text { selection of the most suitable } \\
\text { procedure for preparing } \\
\text { nanoparticles }\end{array}$ \\
\hline & Santos, Garcia 2010 & $\begin{array}{l}\text { AHP, MAFMA, } \\
\text { ELECTRE }\end{array}$ & $\begin{array}{l}\text { creation of a decision-making } \\
\text { model for acquiring medical } \\
\text { equipment }\end{array}$ \\
\hline & $\begin{array}{l}\text { Ferreyra Ramírez, } \\
\text { Calil } 2007\end{array}$ & $\begin{array}{l}\text { Artificial neural } \\
\text { networks }\end{array}$ & medical equipment purchasing \\
\hline & Ginsburg 2005 & $\begin{array}{l}\text { Human factors } \\
\text { engineering }\end{array}$ & $\begin{array}{l}\text { selection of a general-purpose } \\
\text { infusion pump }\end{array}$ \\
\hline & Feldstein, Brooks 2010 & Value analysis & $\begin{array}{l}\text { optimized purchase of } \\
\text { laparoscopic equipment }\end{array}$ \\
\hline \multirow{6}{*}{ 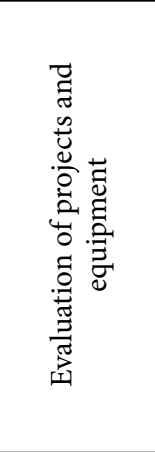 } & Rocha et al. 2005 & \multirow[t]{5}{*}{ AHP } & $\begin{array}{l}\text { selection of services for medical } \\
\text { devices }\end{array}$ \\
\hline & Sloane 2004 & & healthcare technology assessment \\
\hline & Büyüközkan et al. 2011 & & $\begin{array}{l}\text { evaluation of healthcare service } \\
\text { quality }\end{array}$ \\
\hline & Wollmann et al. 2012 & & $\begin{array}{l}\text { assessment of healthcare services } \\
\text { by consumers }\end{array}$ \\
\hline & Topacan et al. 2009 & & $\begin{array}{l}\text { evaluation of users' preference } \\
\text { about health service }\end{array}$ \\
\hline & Ni et al. 2002 & PROMETHEE, GAIA & $\begin{array}{l}\text { evaluation of nanoparticles } \\
\text { enrichment }\end{array}$ \\
\hline 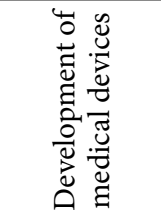 & Li et al. 2011 & AHP & $\begin{array}{l}\text { procedure for developing the } \\
\text { design of medical devices }\end{array}$ \\
\hline
\end{tabular}


Primiano (2001) used AHP for selecting and purchasing intensive care ventilators. Cho and Kim (2003) employed AHP for selecting 88 medical products and materials for development in Korea. Pecchia et al. (2013) designed a CT scanner selection based on 12 specifications. Montevechi et al. (2010) used AHP for ultrasonic scanning system selection in private hospitals in Brazil. Sloane (2004) showed how to build a neonatal ventilator evaluation model. Arikan and Kucukce (2012) applied AHP and the preference ranking organization method for enrichment evaluation (PROMETHEE II) for evaluating criteria and suppliers to minimize economic losses from the inadequate assessment of suppliers. Santos and Garcia (2010) used AHP, Multi-Attribute Failure Mode Analysis (MAFMA) and ELECTRE to demonstrate a decision model for incorporating indicators in the acquisition of hospital medical equipment. Velmurugan and Selvamuthukumar (2012) employed the ANP to assess and select the most appropriate procedure for preparing nanoparticles.

Human factors engineering, which included a heuristic evaluation of instruments and was supplemented by results of end-user testing, made it possible (Ginsburg 2005) to determine the strongest and weakest points of infusion pumps. The negative side is that this method cannot be used for evaluating all types of equipment due to its prohibitive use of time, and human and financial resources. The data obtained could be used as a guide for design changes and modifications of medical devices.

The paper (Ferreyra Ramírez, Calil 2007) described the possibility of using neural networks as the means of artificial intelligence to provide knowledge to experts (clinical engineers) for evaluating offers of medical equipment. The disadvantages of this method are twofold. First, this model only has an $85 \%$ reliability (Ferreyra Ramírez, Calil 2007). Second, in the real world, this model requires numerous iterations and the cooperation of consultants experienced in dealing with such tasks, such as doctors, nurses and managers. The experts' competence was not evaluated in the paper, and therefore the value of opinions expressed by the authors could not be taken into account.

This fact can influence the reliability of the final selection results. Value analysis to optimize the purchase of medical equipment (laparoscopic equipment) was also applied (Feldstein, Brooks 2010). This paper demonstrates that value analysis can be used to develop a model of comparing equipment to be purchased. The model is based on complex costs and known results of deployment of the instrument in clinical practice, and takes into account the economical parameters of healthcare institutions and medical service providers. The limitations of applying this model stem from the disadvantages of the method in question: the process of describing functions can prove excessively detailed; the model is oftentimes too complicated and difficult to support; a quality realization of the model requires special software; and organizational changes often render the model obsolete. The possibility of applying methods of multicriteria analysis to the evaluation and selection of medical equipment and instruments was illustrated in the evaluation of the artificial cardiac valve using AHP (Hummel 2001). The evaluation was based on clinical, economical, social and technical parameters of cardiac valves. Specialists, namely, developers, manufacturers and doctors (cardiologists and thoracic surgeons) have been chosen as experts for the sake of the interdisciplinary task. The research result was a ranked list of cardiac valves, headed by the valve that proved the most 


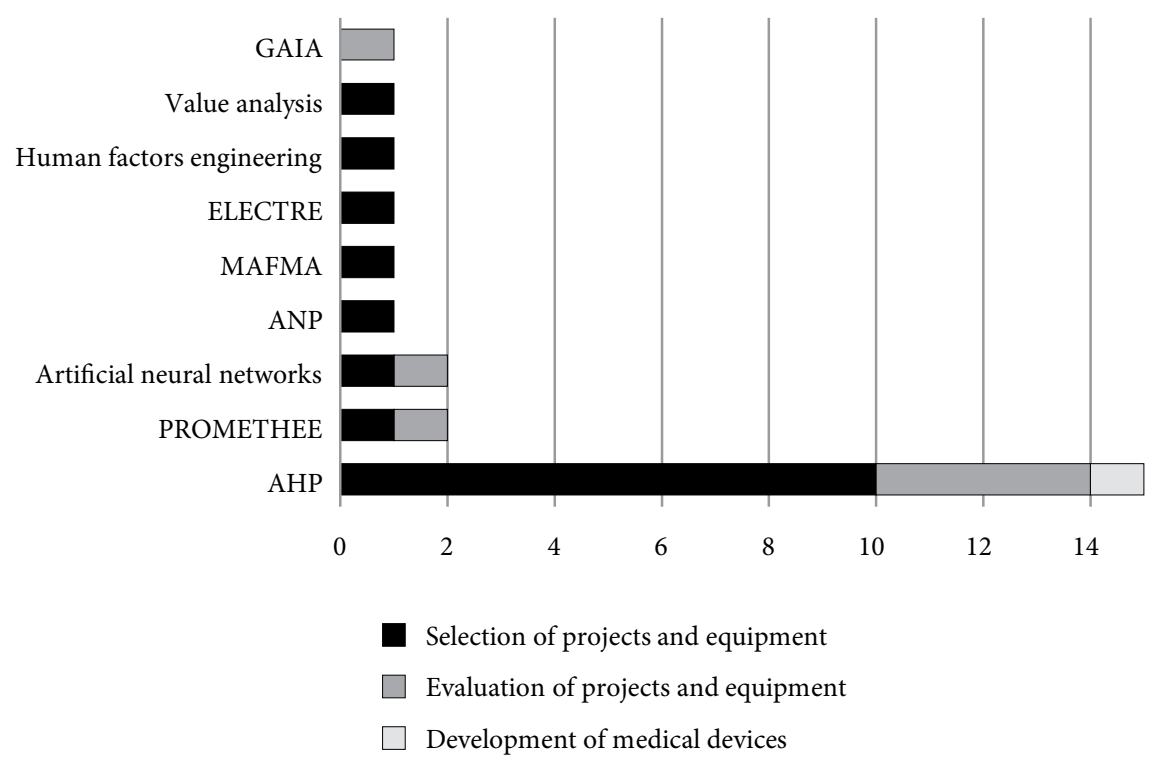

Fig. Use of MCDA methods for management of medical equipment

rational choice within the framework of the given task. Another paper (Mundzhed 2008) that followed a similar logic studied the issue of rational selection of electrocardiographs for first-aid stations.

The application of AHP offered the option that conformed to the technical specifications put forward by experts. The Figure presents the use of MCDA methods for management of medical equipment.

\subsection{Evaluation of projects and equipment}

Attempts have been made (Feldstein, Brooks 2010; Ferreyra Ramírez, Calil 2007; Ginsburg 2005; Hummel 2001) to apply well-known methods to evaluate and select various kinds of medical products.

The AHP has often been applied to the evaluation of projects and medical equipment. Sloane (2004) described a framework to evaluate maintenance service modalities for medical equipment within the decision support system based on AHP. Büyüközkan et al. (2011) applied a fuzzy AHP to develop a decision-making model that can help evaluate the perceived service quality in some pioneer Turkish hospitals. Wollmann et al. (2012) used AHP to assess the quality of services offered by health service providers, according to consumers' perceptions. Topacan et al. (2009) used AHP to evaluate users' preferences about health service. Ni et al. (2002) applied PROMETHEE and geometrical analysis for interactive aid (GAIA) for ranking of computational methods, accompanied by a first derivative pre-treatment of the spectral data matrix as the preferred performing method. 


\section{Criteria for choosing MCDA methods}

Initially, in selecting an MCDA method, the number of choices under evaluation is very important. Certain tasks, especially in design and engineering, can have an unlimited number of options. Provided the number of choices is finite, in principle, the magnitude of this number is irrelevant. However, it is essential to bear in mind that each option to be considered must be evaluated to determine how it corresponds to the criteria. While selecting an MCDA method, it should be understood that the resources spent on data processing depend on their volume.

The following can be used as criteria for selecting an MCDA method: internal conformity and logical validity; transparency; user-friendliness; data requirements that do not contradict the importance of the issue under examination; correlation among available time, human resources, and resources needed for given methods; possibility to perform check analysis; and software availability, if needed (Dodgson et al. 2009). Besides, the method should be as close as possible to the natural, intuitive process typical of humans (Linkov et al. 2006b).

\section{General comparison of MCDA methods}

Table 3 and Table 4 describe the methods used for performing multicriteria tasks in decision-making. These tables show that multi-attribute utility theory (MAUT) and AHP are the most complex. This is due to the use of optimization algorithms, which are not present in outranking methods. Methods applying optimizing approaches use numerical evaluations to determine the advantages of each choice (alternative) on the same scale. Eventually, the derived sets are the result of evaluations combined into a cumulative score of choices and individual criteria. Individual evaluations are summed or averaged; a weighting mechanism can also be introduced to bring out the greater significance of certain criteria against others.

The advantage of MAUT is that it is based on a utilitarian theory, as well as a mathematical theory that enables validating an exact form of general utility function, depending on the DM's preferences (Larichev 2002). In return, utility maximization need not be important for the DM and can be considered as a drawback of MAUT. The aim of MAUT is to find a simple expression to determine the most beneficial solution. At the same time, identifying the strict preferences of the parties concerned takes a long time and financial losses. A significant disadvantage (Dodgson et al. 2009; Linkov et al. 2006b) of the method is a presumption that the DM is capable of performing precise quantitative measurements of quality. The DM's goal in MAUT lies in utility maximization. It is associated with the fact that certain low-evaluated criteria can be compensated for by the high estimation of the other criteria. Therefore, MAUT belongs to the group of multicriteria decision-making methods known as "compensational" (Linkov et al. 2006b).

The method's advantage is its application in the presence of a large number of choices, achieved with the ease of carrying out the comparison procedure. In turn, the result of applying the method (Larichev 2002) enables the evaluation of any choices (including newly emerged ones). 
Table 3. Comparison of MCDA Methods

\begin{tabular}{|c|c|c|c|}
\hline Method & Important elements & Advantages & Disadvantages \\
\hline AHP & $\begin{array}{l}\text { Values of weight- } \\
\text { coefficients and general } \\
\text { evaluation result from } \\
\text { paired comparisons } \\
\text { of criteria and choices } \\
\text { (Linkov et al. 2006b). }\end{array}$ & $\begin{array}{l}\text { User-friendliness of the } \\
\text { application (Formav, Gass } \\
\text { 2001; Charouz, Ramík 2010). } \\
\text { Paired comparisons are } \\
\text { easy to perform (Charouz, } \\
\text { Ramík 2010; Linkov et al. } \\
\text { 2006b). Targeted at } \\
\text { comparison of real choices } \\
\text { (Santos, Garcia 2010). } \\
\text { Axiom of homogeneity and } \\
\text { hierarchical decomposition } \\
\text { principle bring into accord } \\
\text { the problem of receiving } \\
\text { evaluations with human } \\
\text { psychometric abilities } \\
\text { (Linkov et al. 2006b; } \\
\text { Wollmann et al. 2012). } \\
\text { Determines the quality } \\
\text { index quantitatively } \\
\text { (Larichev 2002). Provides } \\
\text { for checking expert } \\
\text { information for lack of } \\
\text { contradictions (Saaty } \\
\text { 2000). Does not require } \\
\text { mathematical models } \\
\text { (Brauers, Zavadskas 2012; } \\
\text { Linkov et al. 2006b). }\end{array}$ & $\begin{array}{l}\text { Critics point out that } \\
\text { weight-coefficients } \\
\text { obtained through paired } \\
\text { comparisons do not } \\
\text { necessarily reflect a } \\
\text { DM's real preferences } \\
\text { (Linkov et al. 2006b). } \\
\text { Mathematical procedures } \\
\text { can produce illogical } \\
\text { results (Brauers, } \\
\text { Zavadskas 2012; } \\
\text { Linkov et al. 2006b; } \\
\text { Saaty 2000). This is a } \\
\text { heuristic approach and } \\
\text { does not guarantee that } \\
\text { a DM's preferences are } \\
\text { presented correctly } \\
\text { (Larichev 2002; } \\
\text { Linkov et al. 2006b). }\end{array}$ \\
\hline MAUT & $\begin{array}{l}\text { Weight-coefficients are } \\
\text { often determined by direct } \\
\text { evaluation of choices } \\
\text { against an absolute scale } \\
\text { (Linkov et al. 2006b). } \\
\text { A utility function is } \\
\text { constructed which is } \\
\text { axiomatically (purely } \\
\text { mathematically) based } \\
\text { (Larichev 2002). Usually, } \\
\text { tasks from the second } \\
\text { group are solved and } \\
\text { the results are used for } \\
\text { evaluation of given choices } \\
\text { (Larichev 2002). }\end{array}$ & $\begin{array}{l}\text { Scientific proof is based } \\
\text { on a utilitarian theory } \\
\text { (Linkov et al. 2006b). } \\
\text { The presence of a } \\
\text { mathematical theory can } \\
\text { validate a specific view of } \\
\text { general utility function, } \\
\text { depending on a DM's } \\
\text { preferences (Larichev } \\
\text { 2002). Applying the method } \\
\text { enables the evaluation } \\
\text { of any choices (including } \\
\text { newly emerged ones) } \\
\text { (Larichev 2002). Can be } \\
\text { applied to many choices } \\
\text { (Larichev 2002). }\end{array}$ & $\begin{array}{l}\text { Utility maximization } \\
\text { does not have to be } \\
\text { important for a DM } \\
\text { (Formav, Gass 2001). } \\
\text { Weight-coefficients of } \\
\text { criteria provided during } \\
\text { a survey by persons with } \\
\text { a low interest can result } \\
\text { in discrepancy with } \\
\text { participants with a high } \\
\text { interest (Linkov et al. } \\
\text { 2006b). Determining } \\
\text { strict preferences of } \\
\text { interested parties } \\
\text { leads to high expenses } \\
\text { (Linkov et al. 2006b). } \\
\text { The method presumes } \\
\text { that a human can perform } \\
\text { precise quantitative } \\
\text { measurements of quality } \\
\text { indexes (Larichev 2002; } \\
\text { Linkov et al. 2006b). } \\
\text { Requires much time } \\
\text { and effort from a DM } \\
\text { (Linkov et al. 2006b). }\end{array}$ \\
\hline
\end{tabular}


Continued Table 3

\begin{tabular}{|c|c|c|c|}
\hline Method & Important elements & Advantages & Disadvantages \\
\hline $\begin{array}{l}\text { OUTRAKING } \\
\text { (ELECTRE) }\end{array}$ & $\begin{array}{l}\text { One option over another } \\
\text { if: "it outperforms the } \\
\text { other on enough criteria } \\
\text { of sufficient importance } \\
\text { (as reflected by the sum } \\
\text { of criteria weights)" and } \\
\text { it "is not outperformed by } \\
\text { the other in the sense of } \\
\text { recording a significantly } \\
\text { inferior performance } \\
\text { on any one criterion" } \\
\text { (Linkov et al. 2006b). } \\
\text { Allows for classification } \\
\text { of choices as "disparate" } \\
\text { (Linkov et al. 2006b). }\end{array}$ & $\begin{array}{l}\text { A staged discovery of a DM's } \\
\text { preferences (Larichev 2002). } \\
\text { The decision rule is not } \\
\text { defined beforehand but is } \\
\text { changed during the process } \\
\text { to take into account a DM's } \\
\text { opinion (Larichev 2002). } \\
\text { Does not require all criteria } \\
\text { to be combined into one } \\
\text { block (Linkov et al. 2006b). } \\
\text { An explicit examination } \\
\text { of a situation in which a } \\
\text { very low effectiveness of } \\
\text { one criterion can exclude } \\
\text { a choice, even if this low } \\
\text { value is compensated for } \\
\text { by very good indexes for } \\
\text { other criteria (Linkov et al. } \\
\text { 2006b). }\end{array}$ & $\begin{array}{l}\text { Only a condition of } \\
\text { supremacy of one choice } \\
\text { over another is established } \\
\text { (Larichev 2002). The fact } \\
\text { that a high weight of one } \\
\text { criterion can compensate } \\
\text { for a low weight of } \\
\text { another one is not always } \\
\text { considered (Linkov et al. } \\
\text { 2006b). The algorithm } \\
\text { does not have to reflect } \\
\text { a DM's true preferences } \\
\text { (Linkov et al. 2006b). } \\
\text { Results are difficult } \\
\text { to interpret (Brauers, } \\
\text { Zavadskas 2012; Larichev } \\
\text { 2002; Linkov et al. 2006b). }\end{array}$ \\
\hline
\end{tabular}

Source: Own compilation based on the literature review.

Both MAUT and AHP methods aggregate different aspects of solving the optimization function, i.e. the target function (Anguilar 2009). The goal of AHP is to select the best choice that exhibits the highest values of the target function. Both AHP and MAUT are used in the compensational optimization approaches. However, unlike MAUT, which is based on evaluations of usefulness or weight functions, AHP uses paired comparisons of each criterion, which creates a matrix of paired comparisons. The application of AHP, as distinct from MAUT, rests on a successful assumption that a human is more capable of performing a comparative analysis (Table 4) rather than producing absolute evaluations, when experts (or DMs) cannot give absolute evaluations according to criteria and revert to weaker comparative measurements. Critics point out that weight-coefficients obtained through paired comparisons do not necessarily reflect a DM's real preferences (Linkov et al. 2006b). Notwithstanding this, the paired comparisons allow AHP to effectively solve a range of practical tasks (Hummel 2001; Linkov et al. 2006a; Mundzhed 2008). Hence, due to a rational presumption about comparative measurements (Linkov et al. 2006b) and the fact that the method does not require mathematical models (Formav, Gass 2001), AHP is a less stressful method for evaluation participants, compared to MAUT (Larichev 2002).

Unlike MAUT and AHP, methods from the outranking family, to which ELECTRE belongs, are based on a principal supposition that one choice can have a degree of supremacy over another (Formav, Gass 2001; Larichev 2002). The ELECTRE method is significantly different from the previously described methods, vis, the decision rule used to make a selection from existing choices, is not determined beforehand, but is changed based on the DM's opinion.

During this process, the DM changes the algorithm parameters, depending on the properties of the considered task, and thus reaches the most acceptable result for him/her (Larichev 2002; Lotov, Pospelova 2008). 
Table 4. Comparison of MCDA methods respect to defined criteria

\begin{tabular}{llll}
\hline \multicolumn{1}{c}{ Criteria } & AHP & MAUT & $\begin{array}{l}\text { OUTRAKING } \\
\text { (ELECTRE) }\end{array}$ \\
\hline Problem decomposition & hierarchy & no & no \\
\hline Evaluation criteria & $\begin{array}{l}\text { obtain the } \\
\text { mechanism } \\
\text { evaluation }\end{array}$ & $\begin{array}{l}\text { requires an } \\
\text { assessment of } \\
\text { evaluation }\end{array}$ & $\begin{array}{l}\text { requires an } \\
\text { assessment of } \\
\text { evaluation }\end{array}$ \\
\hline Subjectivity & large & large & large \\
\hline User-friendliness & easy & difficult & difficult \\
\hline Organization of a research & short & long & long \\
\hline Need time period & easy & difficult & difficult \\
\hline Processing of an obtained result & smaller & bigger & bigger \\
\hline Resources needed (time) & no & no & yes \\
\hline The issue of incomparability of alternatives & yes & no & no \\
\hline $\begin{array}{l}\text { Closely reproduces natural, intuitive, and } \\
\text { human typical process of defining priorities }\end{array}$ & no & no & no \\
\hline $\begin{array}{l}\text { Algorithm for combining } \\
\text { of expert groups opinions }\end{array}$ & & & \\
\hline Source Own compilation. & & &
\end{tabular}

Source: Own compilation.

Dominance becomes apparent when one choice is more effective than another on at least one criterion is not worse than others on all criteria. Outranking methods presume that a situation can occur in which the best choice shall not be discovered. The drawback is that it is not always taken into account that a high weight of one criterion can compensate for a low weight of another. To define and affirm the level of a certain alternative's advantages over the other one, outranking models evaluate the effectiveness of two (or more) alternatives concerning combined criteria.

Thus, these methods collect composite information about preferences for all existing criteria and determine the supremacy of one choice over another. For example, these methods can determine the best choice if it possesses a large number of outstanding criteria.

On the other hand, outranking models are known as "partially compensational"; these methods are more suitable for cases when the criteria metrics are difficult to aggregate, the measuring scales show wide variations, and the values are incommensurable or disparate (Linkov et al. 2006a, b). Unlike other multicriteria evaluation methods, outranking methods possess peculiarities that allow them to solve the issue of disparate choices. This feature becomes especially important when choices become disparate due to certain circumstances (Wang et al. 2009).

\section{Conclusions}

Based on the analysis of the possibility of applying MCDA methods, it was determined that the AHP approach corresponds to major defined criteria for the selection of medical equipment. The AHP method closely reproduces the natural, intuitive and typically human process of defining priorities. This is achieved through the axiom of homogeneity and the hierarchical 
decomposition principle, which brings the problem of receiving evaluations in line with a human's psychometric abilities. Moreover, the process and results of the AHP application are the easiest to understand, when compared to other previously discussed technologies. The AHP method can address the issue of the rational selection and purchase of medical equipment by healthcare institutions at all levels of the organization. This is because it compares real choices, which allows ranking according to priorities and selecting the best. It does not require constructing mathematical models and it can be used for solving problems under uncertain conditions, such as, undoubtedly, those posed by the selection of medical equipment. The analysis showed that all of the methods explored have a significant drawback. For example, the reviewed methods do not have a mechanism for combining the opinions of the expert groups; also, the analysed methods do not take into account the competence of experts in the task of rational selection of medical equipment. These weaknesses should be eliminated in the process of improving the AHP method.

\section{References}

Angelo, A. 2009. Meet the minimum: requirement-based equipment procurement, Biomedical Instrumentation and Technology 43(3): 211-213. http://dx.doi.org/10.2345/0899-8205-43.3.211

Anguilar, S. Č. 2009. Decision making and Brownfield management, $E \&$ M Ekonomie a Management 12(3): 19-32.

Arikan, F.; Küçükçe, Y. S. 2012. Satin alma faaliyeti için bir tedarikçi seçimi-değerlendirme problemi ve çözümü [A supplier selection-evaluation problem for the purchase action and its solution], Journal of the Faculty of Engineering and Architecture of Gazi University 27(2): 255-264.

Balestra, G.; Knaflitz, M.; Massa, R.; Sicuro, M. 2007. AHP for the acquisition of biomedical instrumentation, in Conference Proceedings: Annual International Conference of the IEEE Engineering in Medicine and Biology Society. IEEE Engineering in Medicine and Biology Society. Conference, 22-26 August 2007, Lyon, France, 3581-3584. http://dx.doi.org/10.1109/IEMBS.2007.4353105

Brauers, W. K. M.; Zavadskas, E. K. 2012. A multi-objective decision support system for project selection with an application for the Tunisian textile industry, E\& M Ekonomie a Management 15(1): 28-43.

Büyüközkan, G.; Çifçi, G.; Güleryüz, S. 2011. Strategic analysis of healthcare service quality using fuzzy AHP methodology, Expert Systems with Applications 38(8): 9407-9424. http://dx.doi.org/10.1016/j.eswa.2011.01.103

Charouz, J.; Ramík, J. 2010. A multicriteria decision making at portfolio management, E \& M Ekonomie a Management 13(2): 44-52.

Chatburn, R. L.; Primiano, F. P. Jr. 2001. Decision analysis for large capital purchases: how to buy a ventilator, Respiratory Care 46(10): 1038-1053.

Cho, K. T.; Kim, S. M. 2003. Selecting medical devices and materials for development in Korea: the analytic hierarchy process approach, The International Journal of Health Planning and Management 18(2): 161-174. http://dx.doi.org/10.1002/hpm.703

Dodgson, J. S.; Spackman, M.; Pearman, L. D. 2009. Multi-criteria analysis: a manual [online], [cited 15 September 2013]. Available from Internet: https://www.gov.uk

Feldstein, J.; Brooks, E. 2010 Optimizing medical device buying. Value analysis models can help you improve decision-making process, Materials Management in Health Care 19(5): 20-22.

Ferreyra Ramírez, E.; Calil, S. 2007. Connectionist model to help the evaluation of medical equipment purchasing proposals, in World Congress on Medical Physics and Biomedical Engineering 2006, Vol. 14, 3786-3789. http://dx.doi.org/10.1007/978-3-540-36841-0_958 
Formav, E. H.; Gass, S. I. 2001. The Analytic Hierarchy Process - an exposition, Operations Research 49(4): 469-486. http://dx.doi.org/10.1287/opre.49.4.469.11231

Fotr, J.; Plevný, M.; Švecová, L.; Vacík, E. 2013. Multi-criteria projects portfolio optimization under risk and specific limitations, $E \& M$ Ekonomie a Management 16(4): 71-88.

Ginsburg, G. 2005. Human factors engineering: a tool for medical device evaluation in hospital procurement decision-making, Journal of Biomedical Informatics 38(3): 213-219. http://dx.doi.org/10.1016/j.jbi.2004.11.008

Hummel, J. 2001. Supporting medical technology development with the analytic hierarchy process. Wageningen: Grafisch bedrijf Ponsen \& Looijen bv. 199 p.

Larichev, O. 2002. Teoriya i metody prinyatiya reshenii, a takzhe khronika sobytii v volshebnykh stranakh. $2^{\text {nd }}$ ed. Moscow: Logos. 392 p. (in Russian).

Lerski, R.; Nicholas, S.; Macfarlane, J.; Waugh, S.; McComb, C. 2010. Buyers' guide: MRI systems for breast screening. NHS Purchasing and Supply Agency [online], [cited 15 September 2013]. Available from Internet: http://nhscep.useconnect.co.uk

Li, X. J.; Bin, G. F; Dhilon, B. S. 2011. Model to evaluate the state of mechanical equipment based on health value, Mechanism and Machine Theory 46(3): 305-311.

http://dx.doi.org/10.1016/j.mechmachtheory.2010.11.008

Linkov, I.; Satterstrom, F. K.; Kiker, G.; Seager, T. P.; Bridges, T.; Gardner, K. H.; Rogers, S. H.; Belluck, D. A.; Meyer, A. 2006a. Multicriteria decision analysis: a comprehensive decision approach for management of contaminated sediments, Risk Analysis 26(1): 61-78. http://dx.doi.org/10.1111/j.1539-6924.2006.00713.x

Linkov, I.; Satterstrom, F. K.; Kiker, G.; Batchelor, C.; Bridges, T.; Ferguson, E. 2006b. From comparative risk assessment to multi-criteria decision analysis and adaptive management: recent developments and applications, Environment International 32(8): 1072-1093. http://dx.doi.org/10.1016/j.envint.2006.06.013

Lotov, V. A.; Pospelova, I. I. 2008. Mnogokriterial'nye zadachi prinyatiya reshenii. Moscow: MAKS Press. 197 p. (in Russian).

Montevechi, J. A. B.; Guimaraes, I. F.; Oliveira, M. L. M. D.; Friend, J. D. 2010. Decision-making with multiple criteria in the selection of ultrasound scavenging system in a private hospital in Brazil, International Journal of the Analytic Hierarchy Process 2(1): 14-29.

Mundzhed, H. 2008. Sistema ratsional'nogo vybora medilo-tekhnicheskogo osnashcheniya sluzhby skoroi meditsinskoi pomoshchi. Saint Petersburg Electrotechnical University "LETI”. 140 p. (in Russian).

Ni, Y.; Chen, S.; Kokot, S. 2002. Spectrophotometric determination of metal ions in electroplating solutions in the presence of EDTA with the aid of multivariate calibration and artificial neural networks, Analytica Chimica Acta 463(2): 305-316. http://dx.doi.org/10.1016/S0003-2670(02)00437-3

OECD Health spending continues to stagnate, says OECD. 2013 [online], [cited 15 November 2013]. Available from Internet: http://www.oecd.org/els/health-systems/health-spending-continues-tostagnate-says-oecd.htm

Pecchia, L.; Martin, J. L.; Ragozzino, A.; Vanzanella, C.; Cvognamiglio, A.; Mirarchi, L.; Morgan, S. P. 2013. User needs elicitation via analytic hierarchy process (AHP). A case study on a Computed Tomography (CT) scanner, BMC Medical Informatics and Decision Making 13(2): 1-11. http://dx.doi.org/10.1186/1472-6947-13-2

Rocha, L. S.; Sloane, E.; Bassani, J. 2005. Optimal medical equipment maintenance service proposal decision support system combining Activity Based Costing (ABC) and the Analytic Hierarchy Process (AHP), in Conference Proceedings: ... Annual International Conference of the IEEE Engineering in Medicine and Biology Society. IEEE Engineering in Medicine and Biology Society. Conference, 1-4 September 2005, Shanghai, China, 7103-7106. http://dx.doi.org/10.1109/IEMBS.2005.1616143 
Saaty, T. L. 2000. Fundamentals of Decision Making and Priority Theory with the Analytic Hierarchy Process. $1^{\text {st }}$ ed. Pittsburgh: RWS Publications. 477 p.

Santos, F.; Garcia, R. 2010. Decision process model to the health technology incorporation, in Conference Proceedings: ... Annual International Conference of the IEEE Engineering in Medicine and Biology Society. IEEE Engineering in Medicine and Biology Society. Conference, 31 August - 4 September 2010, Buenos Aires, Argentina, 414-417. http://dx.doi.org/10.1109/IEMBS.2010.5627344

Skinner, B. 2013. Medical devices and healthcare costs in Canada and 65 other countries, 2006 to 2011, Canadian Health Policy, 1-15 [online], [citeted 12 September 2013]. Available from Internet: http://www.canadianhealthpolicy.com

Slach, O.; Koutský, J.; Novotný, J.; Ženka, J. 2013. Creative industries in the Czech Republic. A spatial perspective, E \& M Ekonomie a Management 16(4): 14-29.

Sloane, E. B. 2004. Using a decision support system tool for healthcare technology assessments, IEEE Engineering in Medicine and Biology Magazine 23(3): 42-55. http://dx.doi.org/10.1109/MEMB.2004.1317981

Sorenson, C.; Drummond, M.; Khan, B. B. 2013. Medical technology as a key driver of rising health expenditure: disentangling the relationship, ClinicoEconomics and Outcomes Research 5: 223-234. http://dx.doi.org/10.2147/CEOR.S39634

Topacan, U.; Basoglu, A. N.; Daim, T. U. 2009. AHP application on evaluation of health information service attributes, in Proc. PICMET 2009 Portland International Conference on Management of Engineering \& Technology. IEEE, 2-4 August 2009, Portland, USA, 486-493. http://dx.doi.org/10.1109/PICMET.2009.5262096

Velmurugan, R.; Selvamuthukumar, S. 2012. The analytic network process for the pharmaceutical sector: multi criteria decision making to select the suitable method for the preparation of nanoparticles, DARU Journal of Pharmaceutical Sciences 20(59). http://dx.doi.org/10.1186/2008-2231-20-59

Voronin, Y. 2003. O sostoyanii meditsinskogo oborudovaniya i ispol'zovanii sredstv federal'nogo byudzheta i vnebyudzhetnykh istochnikov, napravlyaemykh na ego proizvodstvo i zakupku, Accounts Chamber of the Russian Federation 5(65): 186-203 (in Russian).

Wang, J. J.; Jing, Y. Y.; Zhang, C. H.; Zhao, J. 2009. Review on multi-criteria decision analysis aid in sustainable energy decision-making, Renewable and Sustainable Energy Reviews 13(9): 2263-2278. http://dx.doi.org/10.1016/j.rser.2009.06.021

Willeme, P.; Dumont, M. 2013. Machines that go 'ping': medical technology and health expenditures in OECD countries. Brussels: Federal Planningbureau Economics Analyses and Forecast, 2013. 20 p. Available from Internet: http://www.plan.be/admin/uploaded/201302120728090.WP_1302_10422_E.pdf

Wollmann, D.; Steiner, M. T. A.; Viera, G. E.; Steiner, P. A. 2012. Evaluation of health service providers by consumers through the Analytic Hierarchy Process Method, Revista de Saúde Pública 46(5): 777-783. http://dx.doi.org/10.1590/S0034-89102012000500003

World Health Organization. 2010a. The world health report: health systems financing: the path to universal coverage [online], [cited 15 September 2013]. Available from Internet: http://www.who.int

World Health Organization. 2010b. World health statistics 2010 [online], [cited 15 September 2013]. Available from Internet: http://www.who.int

World Health Organization. 2013. World health statistics 2013 [online], [cited 15 September 2013]. Available from Internet: http://www.who.int

Zavadskas, E. K.; Turskis, Z. 2011. Multiple criteria decision making (MCDM) methods in economics: an overview, Technological and Economic Development of Economy 17(2): 397-427. http://dx.doi.org/10.3846/20294913.2011.593291

Zolfani, S. H.; Rezaeinyia, N.; Zavadskas, E. K.; Turskis, Z. 2011. Forest roads location based on AHP and COPRAS-G methods: an empirical study based on Iran, E \& M Ekonomie a Management 14(4): 6-21. 
Ilya IVLEV is an Assistant Professor in the Department of Biomedical Technology at Czech Technical University in Prague. He has completed his education at the Siberian State Medical University (M.D. 2003-2009). He holds a Ph.D. in Biomedical and Clinical Technology from the Czech Technical University in Prague (2009-2014). He has worked (2012-2014) as an Instructor and Research Assistant at the Department of Biomedical Technology at Czech Technical University in Prague. He received Grand Prix at the fourth International Young Biomedical Engineers and Researchers Conference (YBERC 2010) (Kosice, Slovak Republic). As an author and co-author he has published 3 monographs and more than 18 other publications dealing with multiple-criteria decision analysis, management and selecting of medical equipment, health technology assessment, and bioinformatics.

Peter KNEPPO worked for the Metra Blansko Company in the Czech Republic, later in the Institute of Measurement Science, Slovak Academy of Sciences as Senior Research Scientist and was promoted to the Scientific Director. As a Technical Director at the Chirana Prema Company he took a leading role in development and implementation of new medical devices, and served as a General Director of the Slovak Institute of Metrology, Bratislava, Slovakia in global metrological system. As a Professor, he teaches courses on biomeasurement, modelling and metrology at the Slovak Technical University in Bratislava, Technical University in Košice, Trencin University in Trencin and Czech Technical University in Prague. He was elected as the member of the Slovak and of the former Czechoslovak Academy of Sciences, Honorary Member of the former Czechoslovak Society of Biomedical Engineering, the chairman of the IMEKO TC-13 "Measurements in Medicine and Biology", the president of the Slovak Society of Biomedical Engineering and the Fellow of the International Academy of Biomedical Engineering. He has published 5 books and more than 300 other publications dealing with measurements and modelling in medicine and metrology thus continuing in research of biomedical measurement and medical instrumentation, especially measurement and modelling of the cardiac electric and magnetic fields, medical metrology and medical devices management.

Miroslav BARTÁK is a Lecturer and Research Fellow at the Faculty of Social and Economic Studies, Jan Evangelista Purkyně University in Ústí nad Labem, Czech Republic. He holds PhD in Public and Social Policy (2008). He is also a Guest Lecturer of Health economics in international comparion at Faculty of economics of the Technical University Dresden, Germany. His research interests include health economics, international comparison of health systems, health policy and public health. He is an author and co-author of four books and about twenty papers in scientific journals, conference proceedings and book chapters. 